\title{
Assessment of Hybrid Concentrated Solar Power-Biomass Plant Generation Potential in Sahel: Case Study of Senegal
}

\author{
Ababacar Thiam ${ }^{1,2}$, Cheikh Mbow ${ }^{3}$, Mactar Faye1,2, Pascal Stouffs", Dorothé Azilinon² \\ ${ }^{1}$ Efficiency and Energetic Systems Research Group, Alioune Diop University, Bambey, Senegal \\ ${ }^{2}$ Latep, Université de Pau et des Pays de l'Adour, Pau, France \\ ${ }^{3}$ Faculté des Sciences et Technique, Université Cheikh Anta Diop, Dakar, Senegal \\ ${ }^{4}$ Laboratoire d'Energétique Appliquée, Ecole Supérieure Polytechnique, Université Cheikh Anta Diop, Dakar, Senegal \\ Email: ababacar.thiam@uadb.edu.sn
}

How to cite this paper: Thiam, A., Mbow, C., Faye, M., Stouffs, P. and Azilinon, D. (2017) Assessment of Hybrid Concentrated Solar Power-Biomass Plant Generation Potential in Sahel: Case Study of Senegal. Natural Resources, 8, 531-547.

https://doi.org/10.4236/nr.2017.88033

Received: June 25, 2017

Accepted: July 31, 2017

Published: August 2, 2017

Copyright $\odot 2017$ by authors and Scientific Research Publishing Inc. This work is licensed under the Creative Commons Attribution International License (CC BY 4.0). http://creativecommons.org/licenses/by/4.0/

\section{Open Access}

\begin{abstract}
Concentrating Solar Power (CSP) is non-existent in Sahel. Such a situation arises from the high investment costs required by these energy infrastructures and from a lack of information on the identification of suitable sites to accommodate them. Conversely, CSP-biomass plants due to lower investment may be an option for CSP penetration in Sahel where Direct Normal Irradiation (DNI) is between $1400 \mathrm{kWh} / \mathrm{m}^{2} /$ year and $2000 \mathrm{kWh} / \mathrm{m}^{2} /$ year and significant biomass potential. This work presents the results of an identification of suitable sites for hybrid CSP-Biomass in the Sahel, case study of Senegal, taking into account the Direct Normal Irradiation, the availability of water, space and biomass potential. The identified sites have a DNI $>1600 \mathrm{kWh} / \mathrm{m}^{2} /$ year. The biogas production capacity is equivalent to $5,096,563 \mathrm{~m}^{3} /$ year. The quantity of Typha Australis, invasive plant in Senegal river valley available is estimated at more than 3 million tons. The capacity of electrical energy in this zone is estimated at $6.89 \mathrm{GWe}$ for an installation surface estimated at 275.61 $\mathrm{km}^{2}$. The establishment of CSP/hybrid plants can also contribute to combat the proliferation of Typha Australis.
\end{abstract}

\section{Keywords}

Biomass, Concentrating Solar Power (CSP), Direct Normal Irradiation (DNI), Hybrid, Typha Australis

\section{Introduction}

The Sahel, a transitional zone between the Sahara desert and the equatorial fo- 
rests, is a semi-arid region that extends from West Africa to East Africa. With an area of 7.3 million $\mathrm{km}^{2}$, the Sahel covers the following countries: Burkina Faso, Eritrea, Gambia, Guinea-Bissau, Mali, Mauritania, Niger, Senegal, Sudan and Chad. The total population of the Sahelian countries was estimated at 125 million habitants in 2013. Their natural growth rates are among the highest in the world, about $2.5 \%$ to $3.8 \%$ [1].

Like other countries in sub-Saharan Africa, access to electricity in the Sahelian countries is limited. Around 32\% of the population has access to energy in 2013 [2]. Among people having no access to electricity, $80 \%$ live in rural areas and remain distant from distribution networks.

In front of this situation, off grids are one of the means of access to electricity for rural communities in the Sahel. The main technologies available for off grids are generators and renewable energy technologies (solar technologies, small hydropower and small wind turbines).

The economic cost and the environmental impact of the use of generators make the choice of off grids fueled by renewable energy sources in the rural areas of the Sahel.

Solar technologies are more suitable in the Sahelian zone because of a high solar potential of around $5.5 \mathrm{kWh} / \mathrm{m}^{2}$ [3] and low hydroelectricity as well as wind potential. Wind speeds are indeed low with national averages ranging from 2 to $3 \mathrm{~m} / \mathrm{s}$ with some peaks of 4 to $5 \mathrm{~m} / \mathrm{s}$ in some localities [4].

Among solar production technologies, thermodynamic solar power plants (CSPs) could be an alternative to decentralized production and contribute to the fight against climate change. Thermodynamic solar power plants (CSPs) concentrate solar rays to heat, a fluid that is directed directly or indirectly to a turbine coupled to an alternator. CSPs offer the ability to store heat that facilitates the management and distribution of electricity. They can be hybridized with a fossil or biomass energy source to ensure continuous production.

In addition to their capacity to generate electricity, CSPs can also meet heating, desalination and cold requirements. Since 2009, the CSPs have grown steadily. Between 2009 and 2013, installed capacity increased from 600 MWe to 3959 MWe [5].

Despite its advantages and progress, CSPs are not yet competitive with other renewable energy technologies. As comparison, the standardized cost of electricity for CSPs is $(0.20-0.35) \mathrm{USD} / \mathrm{kWh}$ for $(0.11-0.28) \mathrm{USD} / \mathrm{kWh}$ to photovoltaic solar energy and (0.06 - 0.12) USD/kWh to wind turbine [6].

Hybridization with lower-cost fuels (biomass or waste) is also a strategy that could help reduce production costs and make CSPs competitive. In addition, while facilitating the management and distribution of electricity with cost advantages, hybrid plants can extend the siting of CSP plants from arid zones to semi-arid or temperate zones.

In addition, while standard CSP plants generally require direct irradiation (DNI) of $2000 \mathrm{kWh} / \mathrm{m}^{2} /$ year or more, CSP hybrid plants can be located in areas where the DNI reaches $1700 \mathrm{kWh} / \mathrm{m}^{2} /$ year [7]. This brings CSP plants closer to 
agricultural regions with high biomass potential and waste disposal areas.

Among hybrid plants at lower cost, hybrid CSP-biomass plants are a well-accepted solution for low-cost, base-load and renewable energy [8] and are a niche for areas with a DNI and Biomass resources.

CSP hybrid plants are beginning to be a reality. In 2012, the first CSP-biomass "Termosolar Borges" hybrid plant is operational in Spain, demonstrating the technical and economic viability of this technology. In 2014, India also launched a project for a $3 \mathrm{MW}$ hybrid CSP-biomass plant equipped with biomass-integrated gasification (SCOPEBIG) [9].

Hybrid plants continue to be the focus of many research activities. Different configurations have been studied. Peterseim et al. [10] evaluated 17 CSP-biomass hybrid configurations in relation to their technical, commercial and environmental performance. Other work has focused on the hybridization of cylindrical parabolic (PTC) plants with biomass [11] [12] [13]. The Linear Fresnel Reflectors (LFRs) have been studied for hybridization with biomass [14]. The hybridization of solar towers with biomass was also discussed [15] [16].

The lack of information on the identification of potential sites with an acceptable DNI and the availability of biomass constitutes an obstacle to the deployment of hybrid CSP-biomass plants in the Sahelian zone. To our knowledge, the identification of potential sites for hybrid CSP/biomass plants has been done only for Australia [17], India [14] and Brazil [18]. There are no studies on the identification of potential sites for CSP/biomass hybrid systems in the Sahelian zone.

This study aims to fill this gap by focusing on the identification of suitable sites for the implementation of hybrid CSP/biomass plants in the Sahel for decentralized electricity generation. The case of Senegal, located at West Africa between $12^{\circ} 08^{\prime} \mathrm{N}$ and $16^{\circ} 41^{\prime} \mathrm{N}$ latitude and $11^{\circ} 21^{\prime} \mathrm{W}$ and $17^{\circ} 32^{\prime} \mathrm{W}$ longitude, is studied because of the high potential for biogas production in areas with high DNI and the presence of large quantities of Typha Australis in the valley of the Senegal River, which is an invasive plant that colonizes cultivated land.

\section{Review of Hybrid CSP-Biomass System Requirement}

\subsection{Direct Normal Irradiation (DNI)}

Like the standard CSP installations, hybrid plants require a high level of direct sunlight. While the threshold value of the DNI of a site for the implantation of a standard CSP installation proposed by some researchers varies from 2000 to $1800 \mathrm{kWh} / \mathrm{m}^{2} /$ year [8] [9], hybrid systems can be implanted in sites of which The DNI $>1700 \mathrm{kWh} / \mathrm{m}^{2} /$ year [11]. According to Peterseim et al. [19], sites with a DNI $>1500 \mathrm{kWh} / \mathrm{m}^{2} /$ year can be considered acceptable for the implementation of CSP hybrid plants.

\subsection{Land Slope}

CSP plant sites must have limit slopes. Cylindrical Parabolic Trough and Linear 
Fresnel Reflectors require zones with a slope of less than $2 \%$. Solar towers and Dish can be installed in sites with a slope of less than $5 \%$, but installation on sites with slopes greater than $2 \%$ can lead to additional installations.

\subsection{Land Requirement}

CSP plants require large areas of earth for the installation of the solar collectors field, the thermal storage system and the power block. The required area varies from one technology to another. For a given technology, the land requirement varies depending on the presence or absence of the thermal storage system and the cooling method of the power block. In this regard, authors have provided values on the areas required by MW in Table 1.

The availability of land and possibly its cost are important issues to consider in choosing a site. In Senegal, land belongs to the state that distributes it to local communities. CSP plant sites should not be in competition with agricultural land, nature reserves, residential and industrial land.

\subsection{Water Requirement}

Water requirements vary from one technology to another. For water-cooled parabolic (PTC) plants, water consumption is 3000 - $3500 \mathrm{~L} / \mathrm{MWh}$ [22], water requirements are approximately $2300 \mathrm{~L} / \mathrm{MWh}$ for Fresnel Linear Reflector (LFR) [22] and the needs of a solar tower are of the order of $2800 \mathrm{~L} / \mathrm{MWh}$ [23].

The majority of CSP-biomass hybrid systems operate with the Rankine cycle (steam generators) in which $90 \%$ of the water is used to cool the steam cycle and the remaining $10 \%$ is used to clean the mirrors. Dry cooling systems can dramatically reduce water consumption but can result in additional costs. In the Sahel, a semi-arid zone, water cooling is more efficient because the outdoor temperature can reach a maximum of $40^{\circ} \mathrm{C}$. The efficiency of air cooling decreases when the outdoor temperature is high. Moreover, the Sahel is marked by a strong presence of dust. Therefore, the hybrid plant site must always have water availability.

Table 1. Field requirements for various solar thermodynamic technologies.

\begin{tabular}{cc}
\hline CSP technologies & Land requirement $\left(\mathrm{m}^{2} / \mathrm{MW}\right)$ \\
\hline Parabolic Trough & 18,000 including power block [20] \\
Solar Tower & $40,000[21]$ \\
& $45,000[20]$ \\
& $83,600[21]$ \\
Linear Fresnel Reflector & $19,166[20]$ \\
& $25,555(1 \mathrm{~h}$ of thermal storage capacity) [20] \\
Parabolic Dish & 34,000 (wet cooling) [20] \\
& 16,000 [21] \\
& 40,460 [20]
\end{tabular}




\subsection{Biomass Potential}

The availability of long-term biomass is an important criterion for the implementation of CSP-Biomass hybrid plants. The biomass taken or used must not have a negative impact on the environment. Biomass can be used as a back-up to a CSP when solar radiation is not sufficient to produce electricity. Alternatively, biomass can also be used to increase the amount of vapor produced or the temperature of the working gas.

Due to environmental constraints and funding opportunities, the share of biomass in a hybrid plant should be less than $30 \%$.

\subsection{Availability of Power Lines}

As with all power generation systems, hybrid CSPs require access to electrical transmission lines to link supply to demand and roads to transport heavy elements from the CSP central office. According to Kirby et al. [24], the distance from the power grid should not exceed $80.5 \mathrm{~km}$ and the site should be accessible by road or rail over $80 \mathrm{~km}$.

\section{Methodology}

Geographic information system (GIS) tools were used to map the availability of direct sunlight in a specific region. This parameter was used as a general indication of areas favorable to the installation of hybrid CSP-biomass plants and analysis of the cooling constraints, slope and availability of biomass. We are also interested in the economic impact of a $1 \mathrm{MWe}$ cylindrical parabolic CSP.

\subsection{Location of Potential Areas Suitable for Hybrid CSP Plants/ Biomass}

This study concerns areas potentially suitable for the installation of hybrid CSPBiomass plants for decentralized electricity generation $(<1 \mathrm{MWe})$ if they comply with the following requirements:

- DNI $\geq 1600 \mathrm{kWh} / \mathrm{m}^{2} /$ year

- Terrain slopes $\leq 2^{\circ}$

- The land should not be located on crop areas, protected areas or reserves

- The land should not be located in residential areas

- The land must be in areas with high biomass potential

- The land must be in an area with a source of water (river or river) or a water source (boreholes and / or wells)

It is important to note that the boreholes provide water for households and for livestock. Moreover, water points polarize many economic activities and benefit from an economic dynamism linked to the access to this precious liquid.

\subsection{Economic Impact of Hybrid CSP Plants Install}

This is a preliminary study to evaluate the construction and maintenance costs, the revenue generated and the number of jobs that can be created with the in- 
stallation of a $1 \mathrm{MW}$ thermodynamic plant from the tool Jobs Economic Development Impact (JEDI) developed by NREL [25]. This model is widely used in the literature to evaluate the benefits of the construction of renewable energy plants [18].

\section{Results and Discussion}

According to the previous methodology, calculations were made to evaluate potential sites for the installation of hybrid CSP-Biomass plants for decentralized electricity generation.

\subsection{Identification of Areas with an Acceptable DNI}

In sub-Saharan Africa except South Africa, weather stations do not have pyranometers and pyrheliometers. Satellite data are generally used to select favorable areas.

Analysis of the Africa's DNI solar map (Figure 1) [26] shows that the DNI in Sahel ranges from $1600 \mathrm{kWh} / \mathrm{m}^{2} /$ year to $2000 \mathrm{kWh} / \mathrm{m}^{2} /$ year. The most favorable areas remain in the eastern part.

As a Sahelian country, the case of Senegal is studied. The most favorable zones in Senegal have a DNI $>1600 \mathrm{kWh} / \mathrm{m}^{2} /$ year according to their solar map are

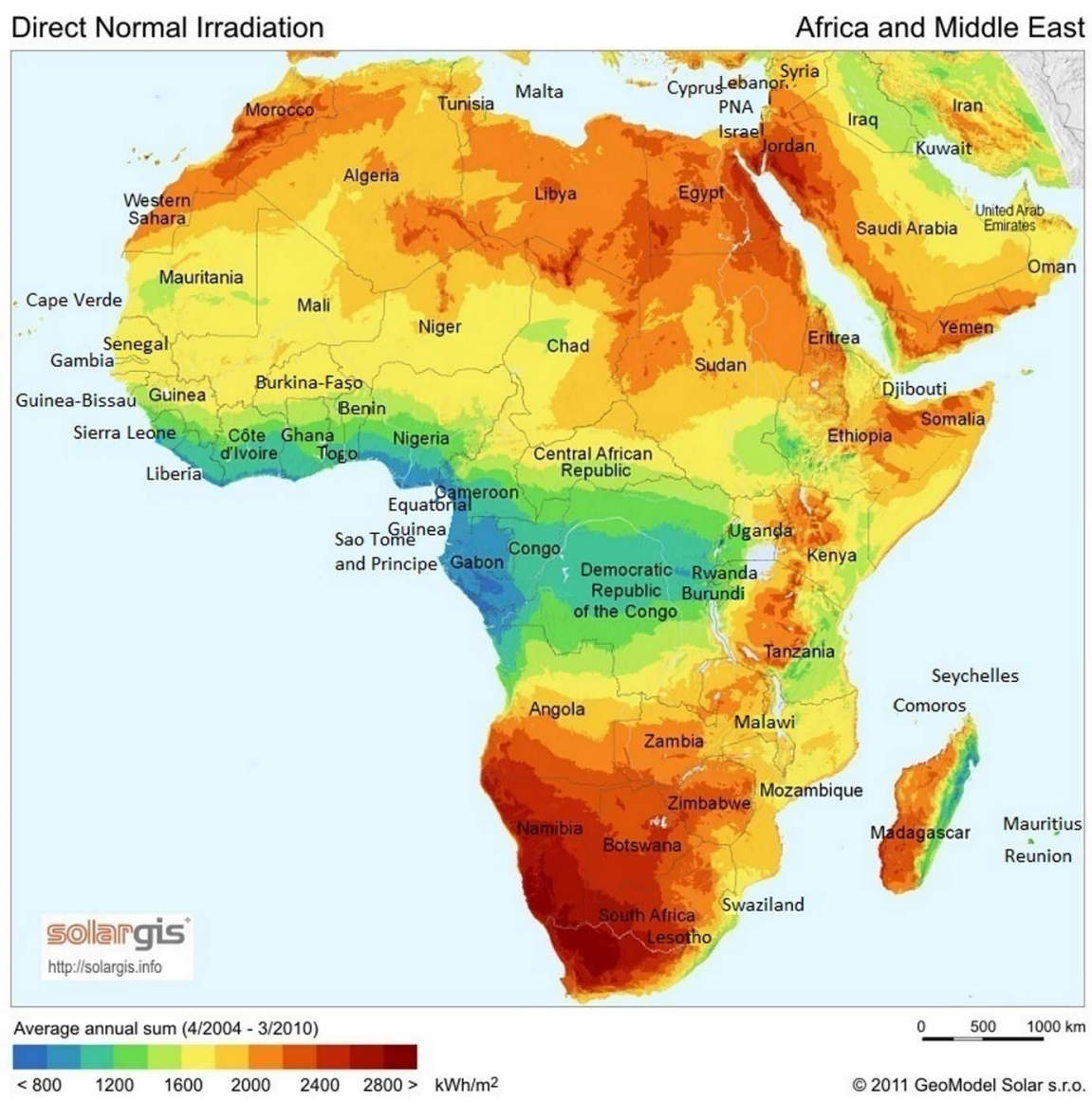

Figure 1. Solar map of Africa. 
located in the North and extend over the administrative regions of Saint-Louis, Louga and Matam and to a lesser extent the regions of Thiès and Diourbel (Figure 2). They cover an area of $73,497 \mathrm{~km}^{2}$ or $37.4 \%$ of the national territory.

\subsection{Estimated DNI and Other Climate Parameters}

The mean monthly values of the direct daily radiation of the departments concerned are obtained from PVGIS [27]. The external temperature and the wind speed come from the six stations of measurement of the climatological data of the national agency of the civil aviation and meteorology of Senegal from 2013 to 2015. Details are shown in Table 2.

Analysis of these data shows that the sites chosen from the solar map have a daily direct radiation greater than $5 \mathrm{kWh} / \mathrm{m}^{2} / \mathrm{d}$. This is the minimum value required for the operation of a CSP. In addition to DNI, the outdoor temperature influences the performance of CSP power stations, particularly on receivers. With the exception of Matam and Ranerou, the average temperature is below $30^{\circ} \mathrm{C}$. It should also be pointed out that the outdoor temperature reaches maxima of $40^{\circ} \mathrm{C}$ during the months of April, May and June in all the localities of the North zone. The average wind speed is relatively low $(<4 \mathrm{~m} / \mathrm{s})$.

\subsection{Eco-Geographical Zones}

The area has little or no difference in elevation (Figure 3), just like the entire Senegalese territory. It can be considered as an important low plateau (slope

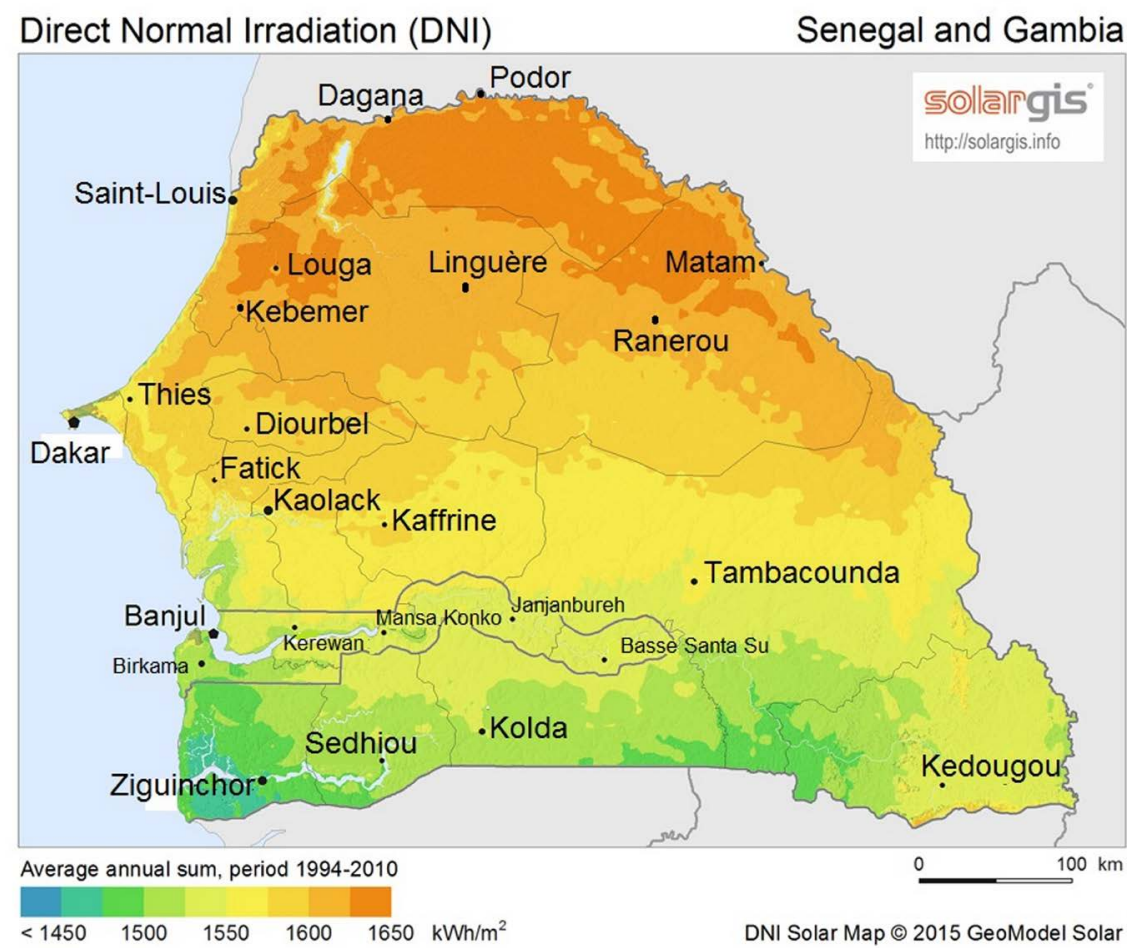

Figure 2. Solar map of Senegal. 
Table 2. Average values of direct normal irradiation, temperature and wind speed.

\begin{tabular}{cccccc}
\hline Departments & Latitude $\left({ }^{\circ} \mathrm{N}\right)$ & Longitude $\left({ }^{\circ} \mathrm{W}\right)$ & $\begin{array}{c}\mathrm{DNI} \\
\left(\mathrm{kWh} / \mathrm{m}^{2 /} \mathrm{d}\right)\end{array}$ & Temperature $\left({ }^{\circ} \mathrm{C}\right)$ & $\begin{array}{c}\text { Wind } \\
\text { speed }(\mathrm{m} / \mathrm{s})\end{array}$ \\
\hline Saint-Louis & 16.21 & 14.8 & 5.55 & 26.5 & 3.26 \\
Dagana & 16.46 & 15.58 & 5.53 & $\mathrm{nd}$ & $\mathrm{nd}$ \\
Podor & 16.66 & 14.95 & 5.52 & 29.7 & 1.34 \\
Louga & 15.61 & 16.21 & 5.64 & 27.9 & 3.00 \\
Kebemer & 15.37 & 16.44 & 5.69 & $\mathrm{Nd}$ & $\mathrm{nd}$ \\
Linguère & 15.38 & 15.22 & 5.59 & 29.8 & 1.99 \\
Matam & 15.66 & 13.25 & 5.78 & 31.0 & 1.60 \\
Ranerou & 15.29 & 13.95 & 5.60 & 30.3 & 2.25 \\
Kanel & 15.49 & 13.18 & 5.60 & $\mathrm{Nd}$ & $\mathrm{nd}$ \\
\hline
\end{tabular}

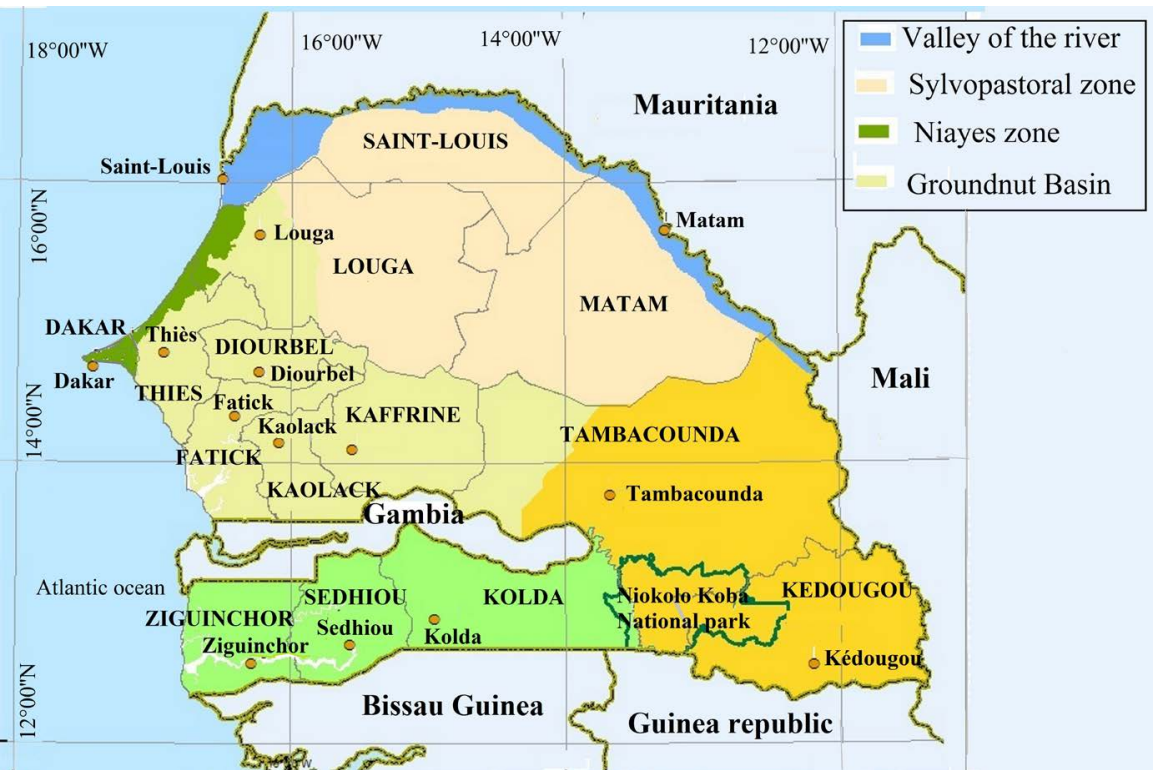

Figure 3. Map of the eco-geographical zones of senegal.

ideally equal to $1 \%$ ) and consists of 4 large eco-geographical zones namely the valley of the river, the Niayes, the groundnut basin, and the sylvo-pastoral zone [28].

- Valley of the river: wet ecosystem due to an important hydrographic network. It has hydromorphic, halomorphic, alkaline, saline, acidified soils and weakly leached ferruginous soils.

- Sylvopastoral zone: it is characterized by an arid climate, the presence of a lake and vast areas of pasture. It has hydromorphic, ferruginous soils with little leaching, reddish brown sandy sub-sandy clay and interbred brown soils.

- Niayes zone: Wet zone due to shallow aquifers with hydromorphic, halomorphic, alkaline, saline, acidified soil and weakly leached ferruginous soils.

- Groundnut Basin: In the old groundnut basin, tropical ferruginous soils are 
leached and degraded on the surface because of intense rainfed crops without fallow. The vegetation cover has become a very rare element and the sand dunes are replenished with the winds strong enough for a good period of the year.

\subsection{Land Availability}

The area with a DNI greater than $1600 \mathrm{kWh} / \mathrm{m}^{2} / \mathrm{d}$ extends mainly to the administrative regions of Saint-Louis, Matam and Louga. It covers an area of 73,497 $\mathrm{km}^{2}$, with housing occupying $2 \%$, protected areas occupying $3.6 \%$ and arable land extending over $19 \%$. The remainder, about $75 \%$, consists of steppes, savannas and fossil valleys (Figure 4).

A more conservative estimate suggests that $0.5 \%$ of this available area can be used to accommodate CSP plants to preserve livestock activities about 2375.6 $\mathrm{km}^{2}$.

\subsection{Water Availability and Rain Fall}

The region has an important potential in water resources distributed in surface water and groundwater.

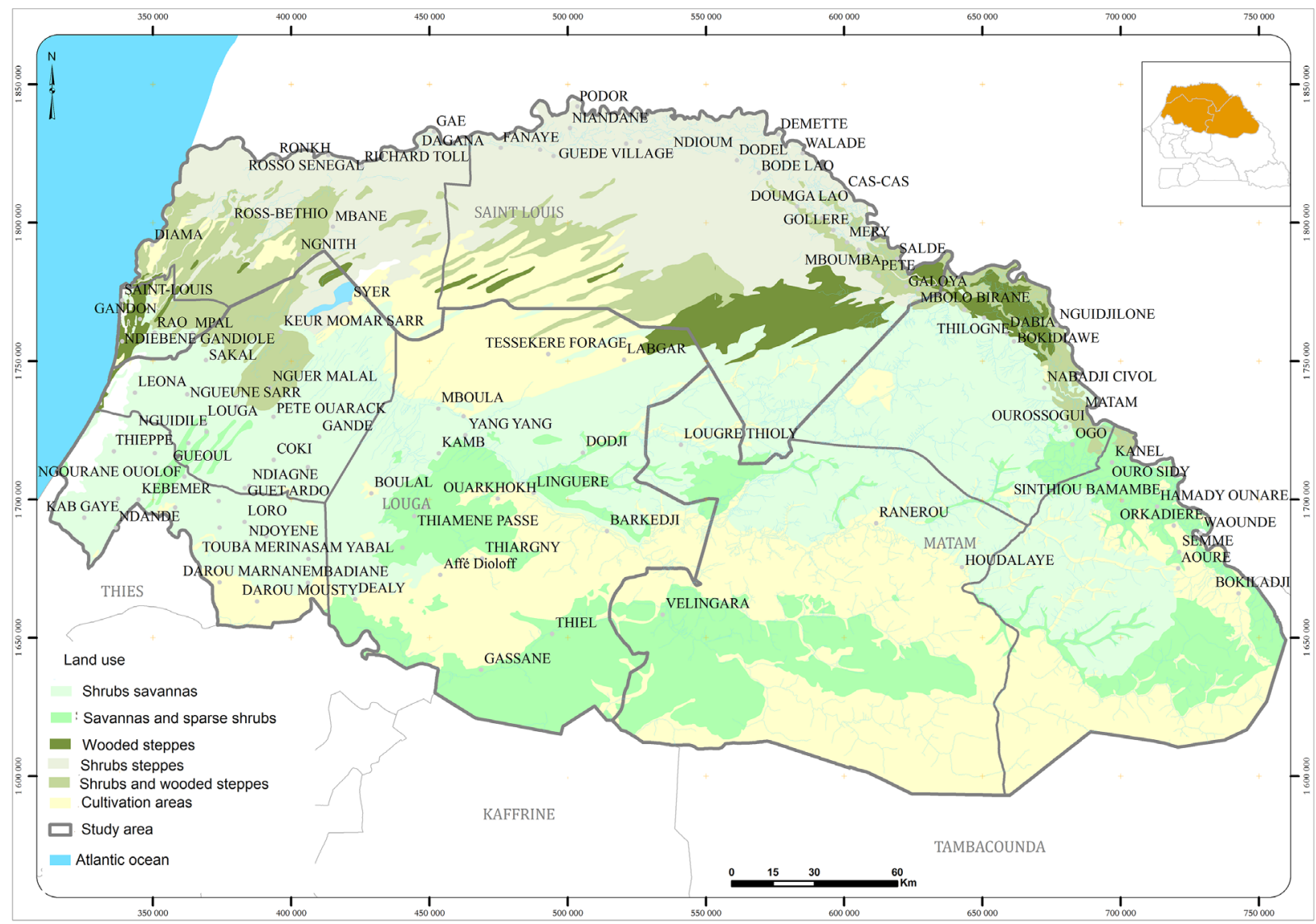

Figure 4. Occupancy map of the area. 


\subsubsection{Surface Water}

The surface water potential is estimated at 23.656 billion $\mathrm{m}^{3}$, of which 23 billion $\mathrm{m}^{3}$ comes from the Senegal River (average annual volume) and 656 million $\mathrm{m}^{3}$ for Lake Guiers. They are mostly concentrated in the valley of the river (Figure $5)$.

\subsubsection{Underground Water}

The underground water potential of the region belongs to the country's aquifer system and is estimated at $1.66500 \mathrm{~m}^{3} / \mathrm{d}$ of which $1.105 .000 \mathrm{~m}^{3} / \mathrm{d}$ is provided by shallow aquifers from wells or boreholes with a maximum depth of about $100 \mathrm{~m}$ and 550,000 m3/d for deep water tables with depths up to $500 \mathrm{~m}$.

\subsubsection{Rainfall}

The average annual rainfall between 2013 and 2015 from weather stations in the area is presented in Figure 5. The rainy season goes from July to August. The rainfall collected shows that the region of the Sahel where isohyets are between $200 \mathrm{~mm}$ and $500 \mathrm{~mm}$.

The year-to-date rainfall of the 6 meteorological stations in the region is shown in Figure 6 [29]. The rainy season takes place during the months of July, August and September.

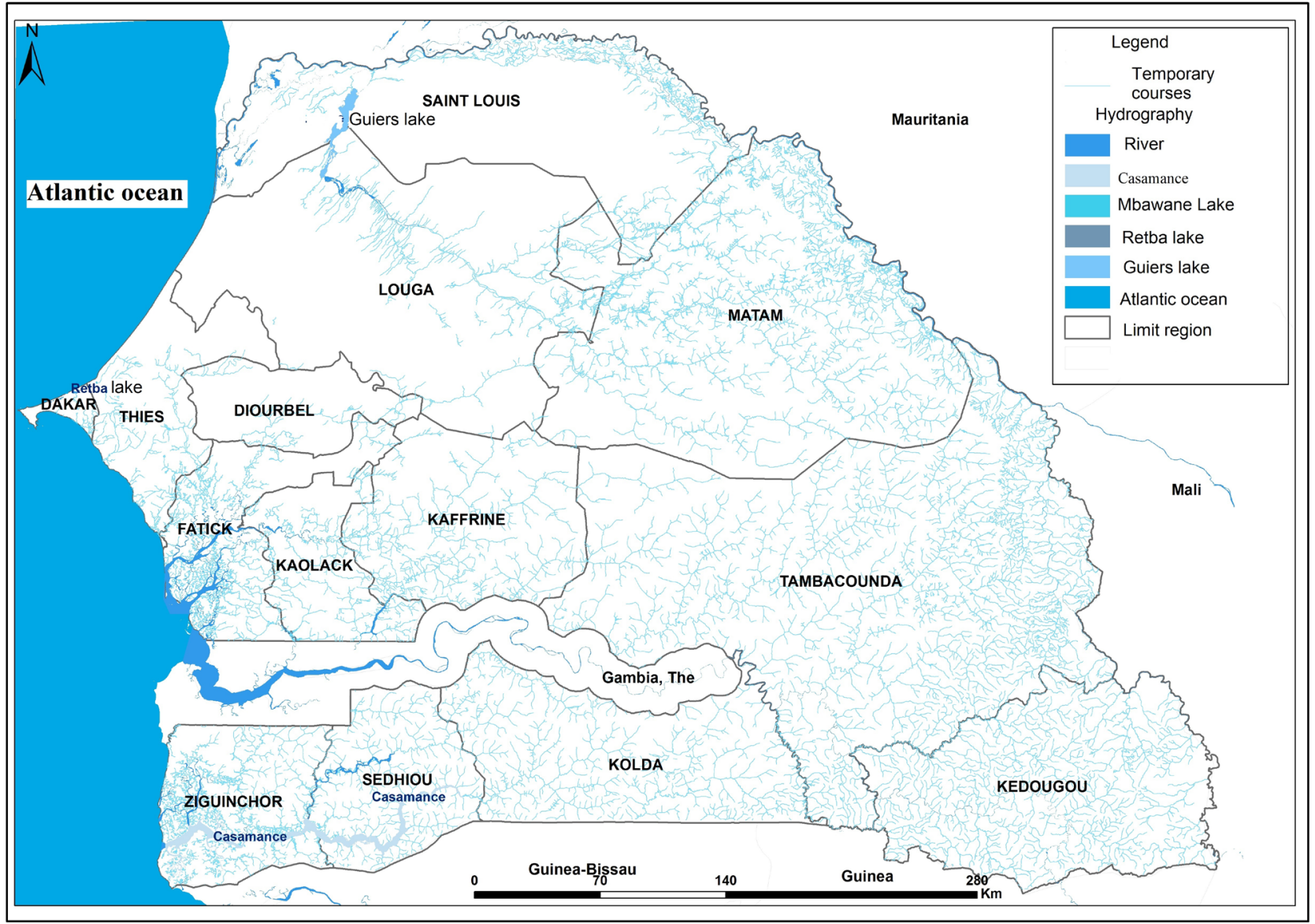

Figure 5. Hydrographic map of Senegal. 


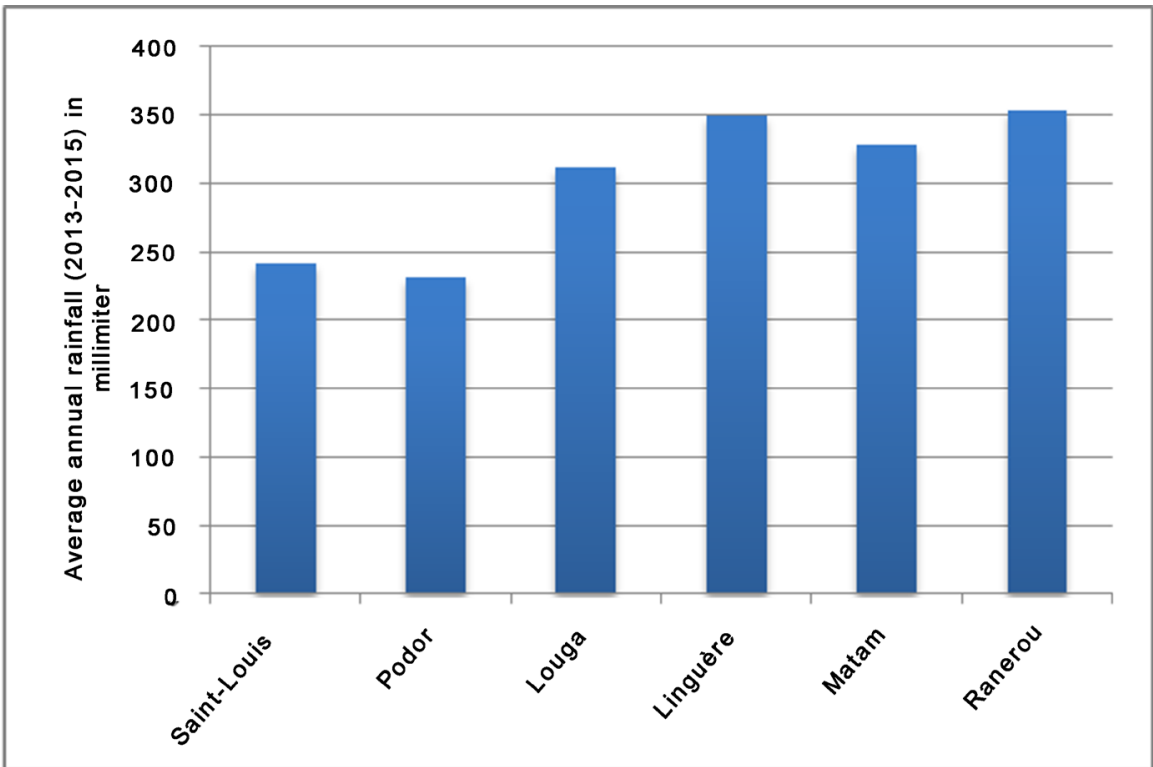

Figure 6. Average annual rainfall in the area with an acceptable DNI.

\subsection{Boreholes}

The region has a large park of boreholes and wells protected or motorized to allow populations and beasts to access to water. The details of the boreholes and pumps can be found in the following table obtained from the Senegal drilling and well directory [30] (Table 3).

In the sylvo-pastoral zone, boreholes provide water for both households and livestock. They polarize many economic activities and benefit from an economic dynamism linked to access to water. However, the drilling remains insufficient. In addition, insufficient water points for livestock watering also cause conflicts between livestock keepers and populations for water use.

\subsection{Biomass Potential}

\subsubsection{Biogas}

The anaerobic fermentation of animal waste produces biogas (about $65 \%$ of $\mathrm{CH}_{4}$, $34 \%$ of $\mathrm{CO}_{2}$ and $1 \%$ of $\mathrm{N}_{2}$ ). This zone is a breeding ground with a large livestock whose number of heads Cattle is approximately equal to $1,228,969$ or at least $4,096,563,333 \mathrm{~m}^{3} /$ year of biogas. Livestock numbers in the region are shown in Table 4 [31] [32] and [33]. In addition, Senegal has a strong biogas production experience through the National Biogas Program. This agency promotes the production and use of biogas in rural areas.

\subsubsection{Typha Australys Plant}

Mali, Senegal and Mauritania are confronted with the phenomenon of the proliferation of Typha Australis. Typha Australis is a rapidly growing reed whose proliferation in the Senegal River basin has accelerated considerably after the construction of dams, notably the 1986 Diama anti-salt dam, which created favorable conditions for its development. Because of its rapid growth, Typha 
Table 3. Distribution and characteristics of boreholes.

\begin{tabular}{cccc}
\hline Departments & Number of boreholes & Debit $\left(\mathrm{m}^{3} / \mathrm{h}\right)$ & Depth $(\mathrm{m})$ \\
\hline Saint-Louis & 3 & $39.6-79$ & $80-558$ \\
Dagana & 52 & $13.8-87.8$ & $26-133$ \\
Podor & 199 & $10.2-99$ & $39-315$ \\
Louga & 205 & $10.5-95.0$ & $40-490$ \\
Kebemer & 353 & $25-86$ & $46-371$ \\
Linguère & 196 & $10.8-82.8$ & $60-637$ \\
Matam & 177 & $10.4-90$ & $50-225$ \\
Kanel & 131 & $12.9-88$ & $50-335$ \\
Ranerou & 69 & $10.2-93.7$ & $55-438$ \\
\hline
\end{tabular}

Table 4. Distribution of livestock species by department in 2013.

\begin{tabular}{cccccc}
\hline Departments & Cattle & $\begin{array}{c}\text { Ovine and } \\
\text { Caprine animals }\end{array}$ & Horses & Asses & Poultry \\
\hline Saint-Louis & 12,490 & 37,570 & 300 & nd & 255,850 \\
Dagana & 78,420 & 118,480 & 1200 & nd & 885,800 \\
Podor & 307,670 & 53,500 & 108,00 & nd & 616,600 \\
Louga & 185,755 & 645,408 & nd & nd & nd \\
Linguère & 235,474 & 992,904 & nd & nd & nd \\
Kebemer & 52,160 & 640,060 & nd & nd & nd \\
Matam & 135,200 & 329,500 & 13,790 & 16,230 & 38,800 \\
Kanel & 126,300 & 264,000 & 9240 & 9880 & 28,500 \\
Ranerou & 95,500 & 302,000 & 15,570 & 14,000 & 53,500 \\
Total & $1,228,969$ & $3,383,422$ & 50,900 & 40,110 & $1,879,050$ \\
\hline
\end{tabular}

nd: not available.

Australis colonizes the flood zones of the Senegal River shared by these countries (Figure 7). It reduces the cultivable areas in the valley. Typha also hampers river navigation and provides a favorable environment for the development of carnivorous birds. In addition, it contributes to the infestation of the waters of the valley.

This invasive plant now covers an area estimated between 60,000 and 80,000 ha on the whole valley. Typha's surface progression in the river valley is $8 \%$ to $10 \%$ per year depending on the area (salinity level) and the biomass weight can reach 120 or $150 \mathrm{~T} /$ hectare [34]. Typha's green biomass was estimated by the Peracod (2012) [34] to be more than 3 million tons, giving about 520,000 tons of dry matter available per year. Typha has a calorific value of $17,000 \mathrm{~kJ} / \mathrm{kg}$ throughout the Senegal River Valley, including Lake Guiers. However, to date 


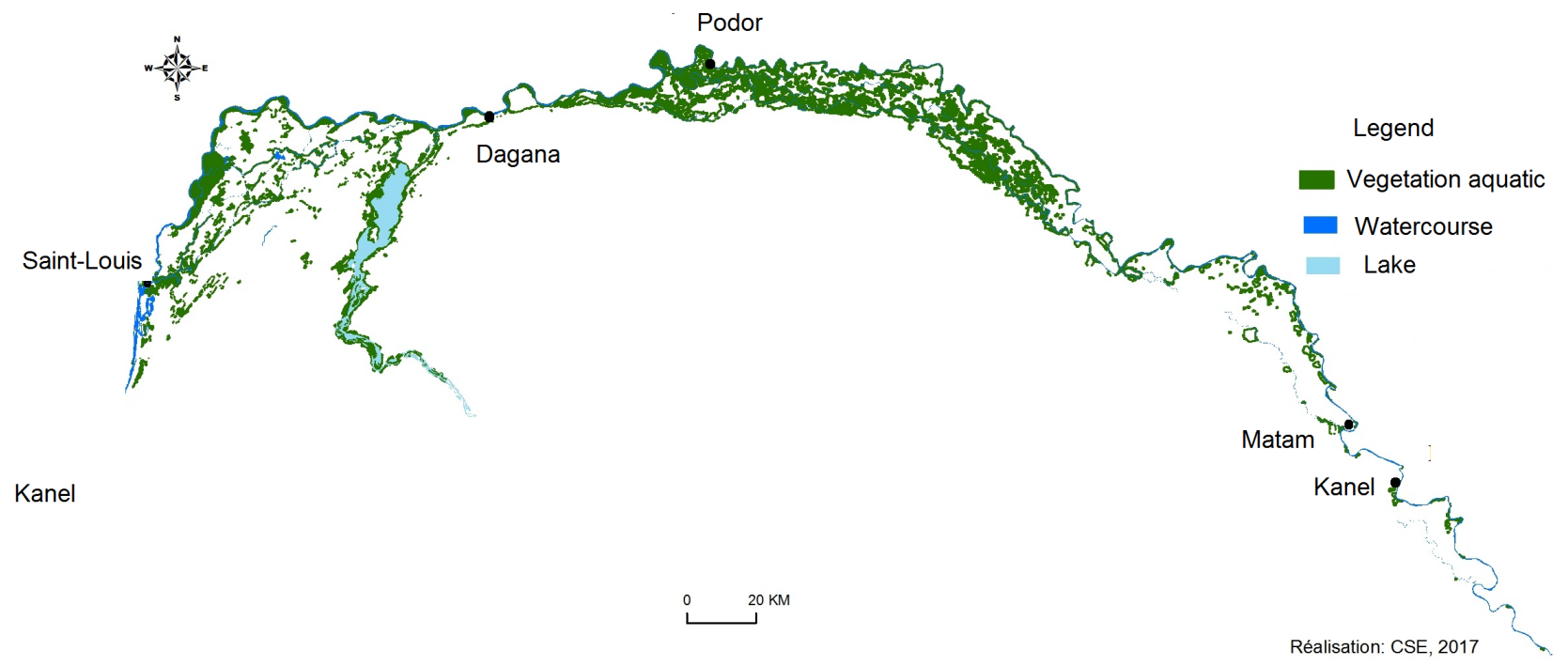

Figure 7. Distribution of aquatic vegetation in Senegal river valley.

there is no biological control. Typha upgrading programs have been explored since the early $2000 \mathrm{~s}$. They involve the use of Typha as domestic fuels through carbonization of biomass into biological coal and as building materials [35].

\subsection{Demand Profile and Grid Connection}

In 2014 , the urban electrification rate is $88 \%$ compared to $29 \%$ in rural areas in 2014. Most of the 39 municipalities are interconnected to the electricity grid (see Figure 7). The chief towns of the 80 communes in rural areas are not all electrified but they benefit from a program of equipment of small photovoltaic power plants and generators. In addition, a program led by the Senegalese agency for rural electrification (ASER) is equipping rural areas with PV plants and generators. At the same time, the Dagana department registered the commissioning of a 20 MW photovoltaic power plant in Bokhol, a locality near Dagana.

The rural world is evolving with the appearance of micro businesses consisting of mechanics workshops, bakeries, dairies, tailors and boreholes that impact on electricity consumption. Indeed, households consume a power of $100 \mathrm{~W}$ to $500 \mathrm{~W}$ while the micro companies (the carpenters, the tailors, the bakeries, the millers) consume more than $1 \mathrm{~kW}$. The boreholes are large energy consumers $(10 \mathrm{~kW}-15 \mathrm{~kW})$. In the sylvo-pastoral zone, it can run up to 20 hours a day during heat periods (Figure 8).

\subsection{Economic Impacts of Plant Construction}

The production capacity is estimated at $50 \%$ of nominal output of a cylindrical parabolic power plant in an area where the annual DNI is equal to $2000 \mathrm{kWh} /$ $\mathrm{m}^{2} /$ year. Therefore, the capacity of production of electrical energy in the region is estimated at $3.45 \mathrm{GW}$, which largely covers the needs of the area.

This region is not very developed, but it has to milk production development potential and agriculture with the cultivation of rice in the river valley. 


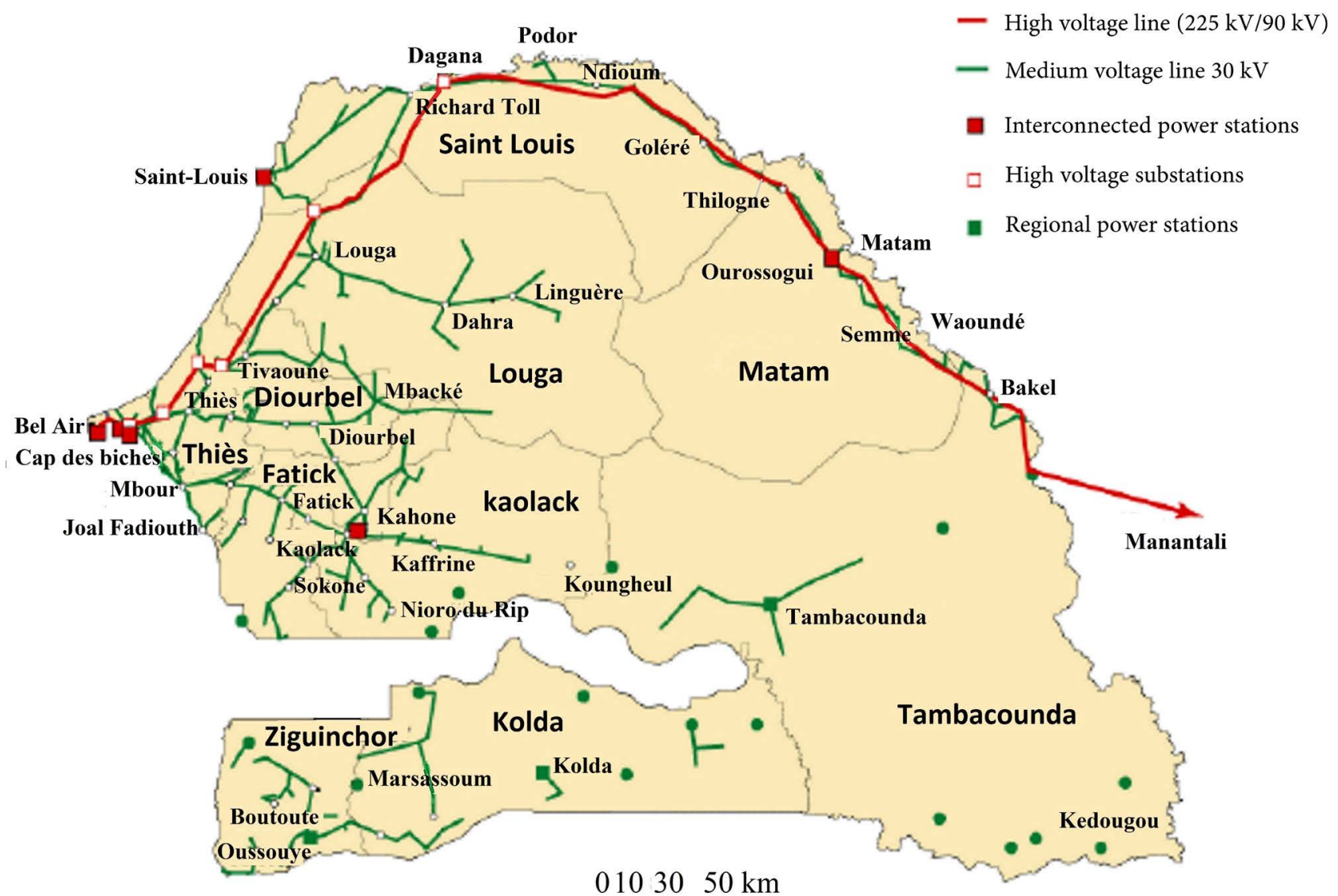

Figure 8. Map of High Voltage and Medium Voltage power lines.

The socioeconomic impact of installing a standard central CSP 1 MW was made using the Jedi tool [13], developed by the National Renewable Energy (NREL) was used to assess the socio-economic benefits Construction of renewable power generation projects in the USA.

The manufacturing cost of the plant is $\$ 7,741,724$ and maintenance costs of $\$ 1,217,927$. During operation, the plant can generate 1.52 million dollars and generate 21 full-time jobs. The construction cost is still high and a reduction in costs may be considering developing a small manufacturing industry. The production cost can significantly decrease if the plant is hybridized with biogas or Typha Australis plant.

\section{Conclusion}

This study shows the feasibility of hybrid CSP-biomass plants as a strategy of penetration into the Sahel. The area identified for the establishment of hybrid power plants in Senegal is located in the northern regions in which direct normal radiation is greater than $1600 \mathrm{kWh} / \mathrm{m}^{2} /$ year. This area also has a significant biomass potential consisting of cow dung due to a large herd and extensive expanses of Typha Australis. The electricity generation potential is estimated at $6.89 \mathrm{GWe}$ for $0.5 \%$ of the available surface area approximately $275.61 \mathrm{~km}^{2}$. The 
establishment of hybrid CSP-biomass plants can allow the development of the production of organic fertilizers from digestate derived from biodigesters and also combat the invasion of agricultural land by Typha Australis. In perspective, we plan to study different hybrid CSP/Biomass configuration according to solar and biomass potentials of the considered sites.

\section{Acknowledgements}

We would like to express our gratitude to the authorities of Alioune Diop University and to Polytechnic Superior School for their support for this project. We would also like to thank the Ecological Monitoring Center and the National Agency of Civil Aviation and Meteorology of Senegal for their technical assistance.

\section{References}

[1] May, J.F. and Guengant, J.-P. (2014) Les défis démographiques des pays sahéliens. Etudes, 4206, 19-30.

[2] International Energy Agency (2014) Africa Energy Outlook: A Focus on Energy Prospects in Subsaharan Africa. 242 p.

[3] Ramdé, E.W., Azoumah, Y., Brew-Hammond, A., Rungundu, A. and Tapsoba, G. (2013) Site Ranking and Potential Assessment for Concentrating Solar Power in West Africa. Natural Resources, 4, 146-153. https://doi.org/10.4236/nr.2013.41A019

[4] Azoumah, Y., Ramde, E.W., Tapsoba, G. and Thiam, S. (2010) Siting Guidelines for Concentrating Solar Power Plants in the Sahel: Case Study of Burkina Faso. Solar Energy, 84, 1545-1553.

[5] International Energy Agency (2014) Technology Roadmap: Solar Thermal Electricity. $52 \mathrm{p}$.

[6] International Energy Agency (2015) Renewable Power Generation Costs in 2014. $164 \mathrm{p}$.

[7] Pérez, Á. and Torres, N. (2010) Solar Parabolic Trough-Biomass Hybrid Plants: A Cost-Efficient Concept Suitable For Places in Low Irradiation Conditions. Solar Paces Conference.

[8] Peterseim, J.H., White, S., Tadros, A. and Hellwig, U. (2013) Concentrated Solar Power Hybrid Plants, Which Technologies Are Best Suited for Hybridisation? Renewable Energy, 57, 520-532.

[9] Indigenous 3MW Solar Power Plant Project Launched in Rural Bihar. Business Standard.

http://www.business-standard.com/article/news-ians/indigenous-3mw-solar-power -plant-project-launched-in-rural-bihar-114120500766_1.html

[10] Peterseim, J.H., Hellwig, U., Tadros, A. and White, S. (2014) Hybridisation Optimization of Concentrating Solar Thermal and Biomass Power Generation Facilities. Solar Energy, 99, 203-214.

[11] Pérez, Á. and Torres, N. (2010) Solar Parabolic Trough-Biomass Hybrid Plants: A Cost-Efficient Concept Suitable for Places in Low Irradiation Conditions. Solar-PACES Conference.

[12] Peterseim, J.H., Tadros, A., Hellwig, U. and Whited, S. (2014) Increasing the Efficiency of Parabolic Trough Plants Using Thermal Oil through External Superheat- 
ing with Biomass. Energy Conversion and Management, 77, 784-793.

[13] Srinivas, T. and Reddy, B.V. (2014) Hybrid Solar-Biomass Power Plant without Energy Storage. Case Studies in Thermal Engineering, 2, 75-81.

[14] Nixon, J.D., Dey, P.K. and Davies, P.A. (2012) The Feasibility of Hybrid SolarBiomass Power Plants in India. Energy, 46, 541-554.

[15] Coelho, B., Schwarzbözl, P., Oliveira, A. and Mendes, A. (2012) Biomass and Central Receiver System (CRS) Hybridization: Volumetric Air CRS and Integration of a Biomass Waste Direct Burning Boiler on Steam Cycle. Solar Energy, 86, 2912-2922.

[16] Peterseim, J.H., Tadros, A., White, S., Hellwig, U., Landler, J. and Galang, K. (2014) Solar Tower-Biomass Hybrid Plants-Maximizing Plant Performance. Energy Procedia, 49, 1197-1206.

[17] Peterseim, J.H., Herr, A., Miller, S., White, S.D. and O'Connell, A. (2014) Concentrating Solar Power/Alternative Fuel Hybrid Plants: Annual Electricity Potential and Ideal Areas in Australia. Energy, 68, 698-711.

[18] Soria, R., Pereira, J.P., Szklo, A., Milani, R. and Schaeffer, R. (2015) Hybrid Concentrated Solar Power (CSP)-Biomass Plants in a Semiarid Region: A Strategy for CSP Deployment in Brazil. Energy Policy, 86, 57-72.

[19] Peterseim, J.H., White, S., Hellwig, U., Tadros, A. and Klostermann, F. (2012) Concentrating Solar Power/Energy from Waste Hybrid Plants-Creating Synergies.

[20] National Renewable Energy Laboratory, USA. Concentrating Solar Power Projects. http://www.nrel.gov/csp/solarpaces/by_status.cfm

[21] Torres, J.M.M., Lopez, N.G. and Marquez, C. (2011) The Global Concentrated Solar Power Industry Report.

[22] Dawson, L. and Schlyter, P. (2012) Less Is More: Strategic Scale Site Suitability for Concentrated Solar Thermal Power in Western Australia. Energy Policy, 47, 91-101.

[23] Sharma, C., Sharma, A.K., Mullick, S.C. and Kandpal, T.C. (2015) Assessment of Solar Thermal Power Generation Potential in India. Renewable and Sustainable Energy Reviews, 42, 902-912.

[24] Kirby, M., Dahle, D., Heimiller, D. and Owens, B. (2003) Assessing the Potential for Renewable Energy on Public Lands. US Department of the Interior and US Department of Energy, DOE/GO-102003-1704, 27 p.

[25] JEDI Models (2013) Jobs and Economic Development Impact Models.

[26] Solargis. http://www.solargis.com

[27] PVGIS. http://re.jrc.ec.europa.eu/pvgis

[28] Agence Nationale de l'Aviation Civileet la Météorologie duSénégal (2016) Climatologie des stations.

[29] Kamara, S. (2013) Développementshydrauliques et gestion d'un hydrosystème largement anthropisé: Le delta du fleuve Sénégal. Thèse de Géographie, Université d'Avignon et des Pays de Vaucluse, $472 \mathrm{p}$.

[30] Ministère de l'hydraulique, Sénégal (2015) Répertoire national des ouvrages. Direction de la Gestion et de la Planification des Ressources en Eau (DGPRE).

[31] Ndiaye, Y., Direction régionale de l'élevage de Saint-Louis, Ministère de l'élevage et des Productions animales, Sénégal (2013) Préparation de la campagne de vaccination de masse du cheptel.

[32] Direction régionale de l'élevage de Louga, Ministère de l'élevage et des Productions animales, Sénégal (2015) Effectif estimé du cheptel régional. 
[33] Agence Nationale de la Statistiqueet de la Démographie, Ministère de l'Economie et du Plan, Sénégal (2013) Situation économique et sociale de la région de Matam.

[34] Programme national de réduction des émissions GES àtravers l'Efficacité Energétique dans le secteur du Bâtiment (2014) Capitalisation des résultats de recherches et expériencessur le typha. $26 \mathrm{p}$.

[35] Projet Sénégaloallemanddecombustibles domestiques (2002) Atelierrégional surles possibilités de valorisation du Typha Australis à des fins de production d'énergies domestiques. $32 \mathrm{p}$.

Submit or recommend next manuscript to SCIRP and we will provide best service for you:

Accepting pre-submission inquiries through Email, Facebook, LinkedIn, Twitter, etc. A wide selection of journals (inclusive of 9 subjects, more than 200 journals) Providing 24-hour high-quality service User-friendly online submission system Fair and swift peer-review system Efficient typesetting and proofreading procedure Display of the result of downloads and visits, as well as the number of cited articles Maximum dissemination of your research work

Submit your manuscript at: http://papersubmission.scirp.org/

Or contact nr@scirp.org 